Canadian Journal of Higher Education Revue canadienne d'enseignement supérieur

Volume 37, No. 1, 2007, pages 95-112

www.ingentaconnect.com/content/csshe/cjhe

\title{
Prior Learning Assessment \& Recog- nition in Canadian Universities: View from the Web
}

Christine Wihak

University of Calgary

\begin{abstract}
Prior Learning Assessment \& Recognition (PLAR), the practice of formally assigning credit for learning gained outside the formal education system (Thomas, 2000), offers significant benefits to adult students. Previous research had demonstrated that adult students may not, however, be aware of the availability of PLAR. This study investigated the availability of PLAR information on the websites of 60 Canadian universities. The research found that 24 Canadian universities offered PLAR for advanced standing. Considerable variation existed in the ease with which PLAR information could be located and in the quality of information provided. Universities were also found to vary widely in the supports offered to learners seeking PLAR, in the formality of their institutional PLAR policies, and in the extent to which the practice is institution-wide or restricted to specific faculties or departments. Findings are discussed in terms of implications for adult learners and their advocates and for future research.
\end{abstract}

\section{RÉSUMÉ}

RDA (Reconnaissance d'acquis), la pratique d'accorder officiellement du crédit pour un apprentissage acquis en dehors du système formel d'éducation (Thomas 2000), offre des bénéfices importants à des étudiants adultes. Des recherches faites auparavant avaient démontré que les étudiants adultes ne seraient peut-être pas au courant du RDA (Schmyr, 2003). Cette étude sur la disponibilité des informations sur RDA dans les sites web de 60 universités canadiennes a eu pour résultat de trouver que 24 universités canadiennes offraient RDA comme dé- 
signation de classification scolaire avancée. La facilité avec laquelle des renseignements sur RDA pouvaient être localisés, de même que la qualité des renseignements, variaient beaucoup. L'appui offert par des universités à des étudiants recherchant RDA variait énormément, et aussi la formalité des politiques de RDA. Il s'agissait de savoir à quel point la pratique s'étendait à tous les départements d'un institut éducatif ou si elle n'était restreinte qu'à des facultés ou des départements bien spécifiques. On étudie les résultats quant aux implications pour des étudiants adultes et pour les recherches futures.

Distinct from the credit transfer process (Larose, 2000), PLAR (Prior Learning Assessment \& Recognition) in the university setting involves giving formal recognition to learning that adult students have acquired informally through work and life experience or through non-credit training and education (Thomas, 2000; Wihak, 2005; Wong, 1999). The Halifax Declaration for the Recognition of Prior Learning 2001 was issued by representatives of multiple stakeholders including education, business, government, labour, and adult education advocates. The argument for universities' involvement in PLAR is based on the need to respond to changing demographics, the expectation that adult students have acquired considerable learning outside the formal education system, and the demand from workplaces that make lifelong learning a necessity (Belanger \& Mount, 1998; Thomas \& Klaiman, 1992; Wong, 1999). According to that document,

the 21st century represents an extraordinary economic environment that includes significant demographic shifts, restructuring of economies and institutions, critical skills shortages, global competition for skilled workers, increased immigration and the relentless progress of technology. In order to maintain quality of life and achieve our goals for economic prosperity, we must support and recognize continuous lifelong learning in all its forms...When individuals are able to demonstrate that they have obtained the necessary knowledge and skills, regardless of where or how that learning has been acquired, appropriate learning credentials must be awarded. Educational institutions...should provide such recognition and accreditation (PLA Centre, 2001, np).

Kreber and Minha (2005) have argued that the Canadian university system must "become an advocate of lifelong learning if society is to subscribe fully to a lifelong learning philosophy" (p.58). To meet this obligation, they suggested that universities need to play a significant role in providing lifelong learning opportunities for adult learners, beyond their accepted role of preparing traditional students to become lifelong learners. They specifically identified PLAR as a university practice to support lifelong learning.

Recent OECD reports $(2002 ; 2005)$ have emphasized the substantial benefits 
that could result from the recognition of prior learning, particularly in terms of stimulating adult learners' motivation to participate in education and training. For adult students, the use of PLAR can significantly reduce the time and cost of completing or upgrading post-secondary credentials (Aarts et al., 2003; Thomas, Collins, \& Plett, 2002). CAEL (Council for Adult and Experiential Learning, 2002), a United States advocacy organization instrumental in catalyzing a worldwide PLAR movement (Evans, 2000a; Thomas, 2000), has identified PLAR policies and procedures as one of the key elements in creating adult-friendly institutions of higher education.

Although PLAR may be of little interest to the universities' traditional clientele of undergraduate students (Keast, 2000), figures from AUCC (Association of Universities and Colleges of Canada, 2003) indicated that adults aged 25 or over represent over half of student enrollments at Canadian universities. A recent Canadian survey on work and learning (Livingstone, Raykov, \& Turner, 2005) demonstrated that many prospective adult students can be expected to have had significant learning experience outside of formal education and further, to be interested in having this experience formally recognized by the educational system if they were offered this possibility. Members of racial minorities and recent immigrants to Canada were particularly interested in gaining recognition for their informal and non-formal learning, indicating the potential for PLAR to contribute to social justice. Another recent Canadian survey, however, found that awareness of the existence of PLAR is very low amongst potential adult students (Shmyr, 2003).

Belanger and Mount (1998) have described PLAR as "a cogent response to the changing learner population" (p. 117). OECD (2002) has specifically recommended research be conducted on PLAR with regard to entering students. While some research has been conducted internationally (Childs, Ingham, \& Wagner, 2002; Merrifield, McIntyre, \& Osaigbovvo, 2000), very little information on this topic is available concerning Canadian universities. This paper presents the results of a fact-finding review of Canadian university websites to determine what PLAR information is readily available to assist prospective adult students interested in gaining credit for informal and nonformal learning acquired through work and life experience.

\section{PLAR in the University Context}

In the university context, PLAR is used for the purposes of granting admission to mature students who lack formal entry qualifications and for granting credits towards a university credential (Thomas \& Klaiman, 1992; Wong, 1999). To assess an individual's learning for PLAR purposes, commonly used methods include challenge exams, interviews, demonstrations, and portfolios that provide documentary evidence of learning (Thomas, 2000). When PLAR is used for granting credits, the individual's learning for credits may be assessed on a course-by-course basis or by granting a block of unassigned credits towards a specific credential (Wong, 1999). 
Evidence exists that university-level learners who earn PLAR credits obtain academic outcomes as good as or better than learners who do not make use of PLAR (Donoghue, Pelletier, Adams, \& Duffield, 2002; Dunlop \& Burtch, 2003; Keeton, 2000; LeGrow, 2000; Pearson, 2000). Research has further shown that the process of preparing a PLAR application can itself be a significant learning experience (Brown, 2002; Geerling, 2003; Thomas, Collins, \& Plett, 2002). Participation in PLAR has also been linked to adult students' persistence towards a degree (Pearson, 2000).

Despite compelling evidence regarding the benefits of PLAR, the introduction of PLAR to universities has been described as problematic for a variety of reasons. A major concern is the challenge PLAR poses to the intellectual foundations of university learning. Thomas (2000) described how PLAR confronts the formal educational system's powerful monopoly on socializing learners and evaluating ability and requires the system to acknowledge that much learning takes place outside of institutional settings. Wong $(1999,2001)$ pointed out that PLAR requires faculty to consider how to accommodate alternative routes through prescribed content, develop clearly stated learning outcomes at different levels of achievement, and articulate a philosophy of assessment; making such changes is a process which in essence involves a realignment of existing curricula. Several authors (Harris, 2004; Michelson, 1996; Peruniak, 1998; Shalem \& Steinberg, 2002; Thomas, 2000) have, however, expressed a different concern about PLAR. They have raised the issue of the disservice that PLAR may represent for experiential learning and alternative knowledge traditions. In the process of aligning such learning to university-defined standards of valued knowledge, any learning that does not readily conform may become distorted and/or devalued.

As discussed extensively by Wong (1999), introduction of institution-wide PLAR raises administrative issues in the university: development of an institutional PLAR policy; articulation of agreements with other institutions concerning acceptance of PLAR credits; consideration of how PLAR will be reflected in faculty workload and reward agreements; development of a policy on how to reflect PLAR results on student transcripts; establishment of valid assessment procedures; provision of faculty training concerning PLAR assessment; enhancement of supports for students wishing to undertake PLAR; calculation of a fee structure for PLAR assessments; and design and distribution of publicity materials for PLAR services. All of these measures obviously have cost implications, a serious consideration for universities with regard to PLAR (Kennedy, 2003).

Despite these concerns, the practice of assessing prior experiential learning has been adopted in universities around the world (Evans, 2000a). Countries where university-level PLAR has been adopted include: the United States (Keeton, 2000), Great Britain (Evans, 2000b; Johnson, 2002), France (Barkatoolah, 2000; Dif, Alsace, \& Strasbourg, 2002; Feutrie, 2000), the Republic of Ireland (McGrath, 2000), Australia (Flowers \& Hawke, 2000; Wheelahan et al., 2002), New Zealand (Ker, Melrose, \& Reid, 2000), and South Africa (Ballim, Omar, \& Ralphs, 2000). 


\section{University Level PLAR in Canada}

Canadian universities have reportedly been "resistant to PLA processes" (Wong, 2001, p. 156). With autonomy from government, universities in Canada have been able to make their own determination about whether and to what extent to become involved in PLAR (Belanger \& Mount, 1998). Belanger and Mount described the status of PLAR in the university sector as "embryonic" (p. 103) and observed that the Canadian Association of Prior Learning Assessment (CAPLA), a national non-profit association formed in 1994 to advocate for PLAR, was "struggling to make itself known in the university community" (p. 102). They attributed this situation to the university prerogative of relative independence from the provincial policies that had accelerated PLAR developments in community colleges. In documenting the Canadian development of PLAR, Blower (2000) characterized it as an initiative primarily of community colleges and provincial governments, with the Quebec government spearheading province-wide implementation at the college level in the 1980s. More recently, regulatory bodies and professional associations in Canada have also become actively involved in PLAR. While specifically identifying Athabasca University in Alberta as a leader in the PLAR field, Blower described Canadian universities in general as continuing to debate the merits of PLAR.

Over the past 15 years, a number of surveys have reported on PLAR in Canadian universities. Thomas and Klaiman (1992) conducted a mail survey of Canadian degree-granting institutions, receiving 65 completed questionnaires. The data indicated that $86 \%$ of the respondents reported using PLAR for admission. Only 30.7\% of respondents, however, reported using PLAR to grant full equivalency for university credits. Responses concerning central administration's delegation of PLAR practice to faculties, schools and departments indicated that less latitude was allowed for admission decisions than for advanced standing decisions. The respondents reported that little special effort was being made to inform prospective adult students about the availability of PLAR. In addition, the responding institutions were generally unable to provide data concerning the number and characteristics of PLAR applicants.

Belanger and Mount (1998) extended the portrait of PLAR in Canadian universities with a survey of Directors of Institutional Research and Continuing Education. Survey questions focused on the institutional profile of PLAR, opinions concerning its appropriateness in higher education, and plans for future development. Based on 74 responses, the authors characterized PLAR in Canadian universities as

- a "sometimes known and spoke of" concept on campus;

- rarely part of the institutional culture

- rarely a priority

- more often seen as a community college issue, rather than a university one;

- more often seen as an extension of continuing education; and

- equally likely to be, or not to be, the object of "formal institutional policy" (p. 105). 
Despite PLAR's reportedly low profile, the majority of respondents in Belanger and Mount's (1998) survey did not concur with the idea that PLAR is inappropriate in universities. Their responses also suggested, however, that universities felt pressured to adopt PLAR by the need to maintain good relationships with labour and industry, as well as by the need to recruit non-traditional students. Nonetheless, the majority of respondents agreed with the idea that PLAR should form part of academic credentials in the future. The authors concluded that study findings indicated "both an openness of the university community towards the PLAR concept and a reluctance to implement it within its own domain" (p. 110).

University ambivalence towards PLAR continued to be evident in a more recent study of Canadian universities (Kennedy, 2003), sponsored by CMEC (Council of Ministers of Education, Canada). That e-mail survey found that only 9 of 29 responding universities possessed a formal PLAR policy, although another six institutions expressed the intention to develop one. In addition, however, informal PLAR practices were reported in 15 of the responding institutions. The existence of a special admissions route for mature students was indicated in 20 of 29 institutions, a figure which is similar to the result found by Thomas and Klaiman (1992).

Kennedy's (2003) study differed from the earlier survey (Thomas \& Klaiman, 1992) in that it provided an indication of the extent to which learners use PLAR, as reflected in the number of PLAR Assessments conducted in the year preceding the survey (2002). Of the 29 responding universities, 26 reported conducting fewer than 50 PLAR assessments a year. Given adults' reported interest in having prior learning recognized in formal education programs (Livingstone et al., 2005), these results lend support to research findings that prospective adult students appear not to be aware of PLAR availability at Canadian universities (Shmyr, 2003). While other barriers to PLAR may exist from the students' perspective, such as the time and cost involved in preparing an application (Wong, 1999), another explanation of low PLAR uptake may be that prospective students simply do not know about the possibility of gaining university credit for informal and nonformal learning. This idea raises the question of what universities are doing to inform prospective students about PLAR.

According to Kennedy's survey (2003), 24 of the 29 responding universities indicated that the institutional website was the primary method that was used to inform prospective students about PLAR policy and procedures. The focus on web-based information provision is in keeping with trends reported in the higher education literature (Foster, 2003; Hossler, 1999). The low number of PLAR assessments reported in Kennedy's study, however, suggested that the PLAR information available on the web may not be adequately informing prospective students about the process. The low demand for PLAR is, however, a concern because universities can use it as a reason to refrain from committing time and resources needed to develop an effective approach to PLAR policies and procedures. The availability of easy-to-find and -use information on PLAR 
for prospective adult students may thus be a key factor in moving PLAR forward in the Canadian university scene.

\section{The Current Study}

Prompted by Kennedy's (2003) findings concerning low rates of PLAR assessments in Canadian universities, the current study adopts the viewpoint of the prospective adult student interested in university-level PLAR (Childs et al., 2002). This research was intended to answer a number of questions: First, is information on PLAR available on Canadian university websites? Second, is such information easy for a prospective adult student to find and use? Third, to what extent does information concerning PLAR indicate the availability of centralized, university-wide policies and/or services to support prospective adult students wishing to apply for PLAR?

Given research reporting universities' increasing emphasis on the use of web pages to provide information to prospective students (Foster, 2003; Hossler, 1999; Kennedy, 2003), a research method that involved a systematic search of university web sites for information on PLAR was deemed appropriate for this investigation. Such web-based research methods have been used in other recent studies of higher education institutions (Childs, Ingham, \& Wagner, 2002; Kreber \& Minha, 2005; Thompson, 2000).

\section{METHOD}

\section{Population}

The population for this study was defined as Canadian universities with membership in the Association of Universities and Colleges of Canada. From that organization's website, we compiled a list of all member institutions whose name identified them as a "University," yielding a total of 60 universities.

A study of PLAR in B.C. (Carrie et al., 2001) distinguished universities from university colleges for the purposes of data analysis because of the different legislative status of the two institutions and the provincial government's ability to influence their adoption of PLAR. Since we were unable to locate a current and comprehensive compilation of the governance status of AUCC members whose names included the terms "college" or "university college" we decided to exclude them from the study. This decision was made because the governance histories of these institutions and their relationship to universities vary widely. While some of these institutions may be able to establish PLAR policies and procedures independently in a manner similar to AUCC's university members, others may be required to follow those of a provincial government or an affiliated university. Including findings from the latter type of institution would have distorted the study results by in essence double-counting universities that govern one or more affiliated colleges, while including findings from university colleges required to follow provincial policies would have inflated the willingness of the university sector to engage in PLAR voluntarily. We also excluded 
institutions with a fine arts only mandate, because of the limited range of programs they offer.

\section{Data Collection}

The method used for data collection involved a systematic search of university websites for information related to PLAR. Such web-based research (Childs, Ingham, \& Wagner, 2002; Kreber \& Minha, 2005; Thompson, 2000) is essentially a contemporary form of reviewing documentary evidence, which is a widely accepted research method (Patton, 2002).

Data collection took place in January, 2006. Two research assistants conducted searches of university websites in the role of prospective students. One of the research assistants was fluently bilingual and conducted the searches on the websites of Francophone universities. Both had computer literacy skills and a layperson's familiarity with searching the web, but no special training in webbased research. Neither research assistant had more than superficial familiarity with PLAR.

First, the searchers were instructed to assume that they were mature students interested in returning to school for undergraduate studies and that they had heard something about "getting credit for experience," but were not familiar with the specific terms Prior Learning Assessment or PLAR; this scenario was based on research findings that indicated low awareness of the term PLAR amongst potential adult learners (Shmyr, 2003). The searchers then conducted a 15 minute search of each institutional website, starting from the home page, a time allowance derived from the procedure used by Child et al. (2002). They looked initially for a link labeled Prospective Student or something similar, and proceeded from there until they found a web page that clearly provided information that was relevant to a prospective student interested in obtaining credit for experience. If a thorough search using the link-following strategy yielded no results and came to a dead end, the research assistants switched to the strategy of entering the term "credit for experience" into the institution's website search engine for Anglophone universities and the terms "l'echange des credites pour la travaille professionelle," "la recognition du travaille professionelle," "la recognition du travaille en advance" and "l'echange des credites pour la travaille" for Francophone institutions. They then searched for the remainder of the 15 minutes. If either part of this two-part strategy yielded appropriate information, the URL was recorded and the information downloaded for later analysis.

Following the initial 15 minute period, the research assistants then adopted a different search strategy, entering the terms "prior learning assessment" and/ or "recognition of prior learning" for Anglophone institutions and "reconnaissance d'aquis" for Francophone institutions into the website's search engine. Relevant URLs found within another 15 minute period were then recorded, with the information downloaded for analysis.

To minimize the impact of learning from previous searches, the research assistants were instructed to follow the same basic procedure for each institution's 
website, as if they had not looked at others; that is, they continued to adopt a naïve stance with regard to PLAR during the initial 15 minute search period. Because the design, structure and operation of each website was different, however, the research assistants had to use their own judgment concerning which links to follow, when to use the "Back" button, when to return to the "Home" page to proceed down a different trail, or whether or not to use quotation marks when entering a phrase into the search engine. They also had to use their judgment in determining whether a particular page provided information relevant to them in their roles as prospective students. This was particularly challenging when a search engine had to be used, since on many websites, the phrase "credit for experience" could return dozens and sometimes hundreds of documents that contained "credit" or "for" or "experience," with similar results for "prior learning assessment."

\section{Data Analysis}

Information Availability. Using the information recorded during the website search procedure, we first categorized institutions in terms of whether information on credit for experience was found, regardless of search route. We also categorized institutions in terms of whether a special admissions route was available for mature students, again regardless of search route.

Information Quality and Search Route. For those institutions where information on credit for experience was found, we rated the information in terms of how useful it would be to a prospective student in terms of three categories: Easy to Use (information on how to apply for credit for experience and/or who to contact); Plain Language Policy (information outlines the availability of PLAR but does not provide extensive information on application procedures or supports); Technical Language Policy (information provided only in the formal language of regulations in a university calendar and/or policy document). We next categorized the institutional data in terms of which of the three search routes (Prospective Student links, "Credit for Experience" search and "Prior Learning Assessment" search) yielded relevant information, counting only the first successful route. That is, if the prospective student strategy provided the information, the institution was placed in that category, regardless of whether the information could also be found by the other two search strategies.

PLAR policies and procedures. A second analysis of the recorded information from the institutional web pages was then conducted to categorize institutions according to whether a formal university policy adopted by the university's governing body existed, and if so, whether PLAR was required to be available in all programs or whether it was offered at the discretion of the faculty, school, department, or program. In addition, we identified whether PLAR applications were submitted through a centralized, university-wide service or made directly to individual faculties, schools, departments, or programs. We further identified the nature of the supports available to prospective students preparing a PLAR application. 


\section{Ethical Considerations}

Because this research involved publicly available information, formal ethics approval was not necessary. Recognizing, however, that university websites change frequently, we refrained from using institutional names in reporting our findings. The information we collected may be revised by the time these findings are published.

\section{FINDINGS}

\section{Information Availability}

Our first research question concerned whether or not information on PLAR credits was available on Canadian university websites. Overall, we found that 24 of the 60 institutions (40\%) investigated had information pertinent to an adult learner interested in obtaining PLAR credits for informal and nonformal learning. Search results also indicated that an additional 28 institutions provided information concerning a special admissions route for mature students that took work and life experience into consideration without assessing such experience towards the granting of formal credit.

\section{Information Quality and Search Route}

Our second research question was whether PLAR information on university websites was easy for a prospective adult student to find and use. The crosstabulation of Information Quality by Search Route for the 24 institutions that offered PLAR for credit appears in Table 1. Eleven of the 24 institutions found to offer PLAR credits had information that was both Easy to Use and Easy to Find; that is, it could be found by a prospective student unfamiliar with the technical terms for PLAR either by following Prospective Student links or by using the "Credit for Experience" search strategy.

Table 1. Quality of Information by Search Strategy

\begin{tabular}{lccc}
\hline \multicolumn{3}{c}{ Easy to Find } \\
\hline & $\begin{array}{c}\text { Prospective } \\
\text { Student links }\end{array}$ & $\begin{array}{c}\text { "Credit for experi- } \\
\text { ence" Search }\end{array}$ & $\begin{array}{c}\text { "Prior Learn- } \\
\text { ing Assessment" } \\
\text { Search }\end{array}$ \\
\hline Easy to Use & 6 & 5 & 5 \\
Plain language policy & 1 & 3 & 2 \\
Technical language policy & 1 & 1 & 0 \\
\hline
\end{tabular}

Plain language policies without additional information concerning PLAR application procedures could be found on six of the websites. At four universities, these policies could be found by using either the Prospective Student links or the Credit for Experience search. Plain language policies at the remaining two institutions could only be found by using the "Prior Learning Assessment" search. 
An additional five institutions had Easy to Use information but it was only accessible through the "Prior Learning Assessment" search. That is, it could only be found by a prospective student familiar with the technical term for the process of having nonformal and informal learning assessed for credits.

\section{PLAR Policy and Procedures}

Our third research question was the extent to which PLAR information indicated the availability of centralized, university-wide policies and services to support prospective adult students wishing to apply for PLAR.

We found formal policies requiring institution-wide PLAR at three universities. Formal policies at eight universities gave faculties, departments and programs discretion with regard to PLAR availability. One institutional policy specified that it offered PLAR only in the faculties of Arts, Engineering, Health Sciences, Management, Sciences, and Social Sciences.

Another nine institutions had web pages referring to faculty or program specific PLAR, without having a university level policy concerning PLAR, or, at least, not one that our search strategies located. In terms of program-specific PLAR, our search found two related to nursing, and one each to social work, optometry, and dentistry. An additional four institutions had web pages related to continuing education programs. In one of these, PLAR was restricted to a Certificate in Adult and Continuing Education. In another, PLAR applied only to non-credit courses although many of the courses offered were accredited by a variety of professional associations. A third offered PLAR only for a restricted selection of courses offered through distance learning.

Nine of the universities appeared to have a central PLAR service, and the web pages referred interested students to a PLAR office and/or co-ordinator. However, only two of these institutions also had a university-wide policy requiring PLAR to be available in all programs.

Only four of the universities explicitly stated that PLAR was available in the form of unassigned credit towards a program of studies rather than on a course-by-course basis. Portfolio assessment was the primary method for PLAR at five universities. At two of these institutions, students were offered credit courses in Portfolio Development to prepare their PLAR applications. Another university offered a non-credit portfolio development workshop, while one both offered a non-credit workshop and referred applicants to an external agency that provided this service. Five universities provided an on-line guide to assist students in preparing a portfolio, including an excellent guide in French that provided case study examples. The remaining institutions referred to using a variety of assessment methods, including assessment of formal and non-formal credentials, challenge examinations, demonstration of skills, and interviews. 


\section{Limitations of the Findings}

The findings of this research were based on publicly available information on institutional websites of Canadian universities. Every effort was made to ensure that the information collected was accurate, given the prescribed search strategy for the study. While the findings provided a reasonably accurate snapshot of the availability of PLAR information on university websites, the extent to which the information was a complete representation of institutional policies and practices is, however, unknown. Quebec, for example, is known as a leader in the PLAR field (Blower, 2000) yet our search strategy did not find relevant information on all university websites in that province.

\section{DISCUSSION AND CONCLUSIONS}

Prompted by concern about reportedly low numbers of requests for PLAR (Kennedy, 2003), this study was undertaken to explore the availability and quality of information on university websites concerning PLAR. The ambivalence towards PLAR observed by Belanger and Mount (1992) apparently continues to exist in the university system. Information for prospective adult students who are interested in gaining formal educational credits for their informal and nonformal learning was easy to find and use only on a few websites. This lack of clear, accessible information on university websites and prospective adult learners' lack of knowledge about PLAR (Shmyr, 2003) seems almost certain to ensure that demand for PLAR will stay low.

While the results of this study are modestly encouraging for adult learners because a higher percentage of universities now offer PLAR than in an earlier study by Thomas and Klaiman (1992), institutions that grant PLAR credits remain in the minority. This finding suggests that the call made by those authors for a "fundamental confrontation between agencies of formal education, and hitherto unconventional students" (p. 23) has yet to be heeded by the majority of Canadian universities.

Considerable barriers to prospective adult students accessing PLAR continue to exist beyond the sheer lack of information on the topic. As in earlier studies (Kennedy, 2003; Thomas \& Klaiman, 1992), more universities indicated a willingness to take prior learning into consideration for admission rather than for credit towards courses or programs. For universities, this approach is a low-risk option since they do not have to chance devaluing their credentials in doing so, a concern which many institutions have expressed about PLAR (Belanger \& Mount, 1998; Kennedy, 2003). While this type of policy benefits adult learners not able to meet formal admission requirements, it does little for the many adults who already meet those requirements and have acquired significant learning through work and life experience that could be recognized for credit towards a credential. Program-based PLAR, a practice which is much more likely to yield results for adult learners than course-specific assessment (Wong, 1999) was generally not available nor were supports to assist a prospective adult student to 
prepare a PLAR application. Further, only a very few universities required all programs to offer PLAR, with most leaving the decision to individual organizational units, reinforcing earlier observations that willingness to engage in PLAR varies across disciplines (Belanger \& Mount, 1998; Wong, 2000).

Nevertheless, several Canadian universities appeared to have made a commitment to use PLAR for granting credits towards a formal credential. These institutions provided information on institutional websites that is easy for prospective adult students unfamiliar with the technical term for prior learning recognition to find and use. Practices at a few of these institutions are exemplary, including extensive information on application processes available in clear language, portfolio courses or workshops, PLAR advisory services, and student guidebooks. These supports would be particularly helpful for disadvantaged learners such as immigrants who have expressed a strong interest in having their prior learning recognized (Livingstone, Raykov, \& Turner, 2005).

The attitude of other universities to these PLAR exemplars may be mixed. In these days of distributed learning, offering PLAR may give an institution a competitive advantage in recruiting adult students (Belanger \& Mount, 1998). Universities seeking to improve their own PLAR policies and procedures could then look to the PLAR policies and procedures of the early adopters for guidance in how to overcome administrative and epistemological barriers to PLAR (Wong, 1999). Alternatively, some universities may prefer to remain focused on their traditional undergraduate students and simply allow adult students to be served by institutions such as Athabasca University that already have an established reputation with regard to PLAR (Blower, 2000).

What are the implications of this study for adult learners seeking credit towards a university credential on the basis of prior learning or for their advocates? First, adult learners need to be persistent in interrogating their chosen institution(s) concerning the availability of PLAR for particular courses or programs. They cannot count on PLAR being offered at a given institution or information about how to apply for it being readily available even in institutions with a formal PLAR policy.

Second, advocates for adult learners, such as Continuing Education units (Belanger \& Mount, 1998), need to inform prospective adult students about PLAR and its possible availability, encouraging them to request it. Within the university, they can endeavor to ensure that the institutional website contains clear information about what PLAR is and how it is beneficial for prospective adult students, in addition to PLAR policy and procedures. Such information needs to be linked directly to Prospective Student or Mature student website entry points. In addition, universities need to use their on-going relationships with community organizations and employers that have contact with potential adult learners to disseminate information about PLAR. Continuing Education units also need to build relationships with disciplinary areas to encourage greater use of PLAR, drawing attention to universities where PLAR is already in use within different disciplines. Another avenue would be to work with existing relation- 
ships with professional and occupational associations, asking these groups to advocate with their university counterparts to provide PLAR for adult students.

The majority of Canadian universities continue to resist external pressures to introduce PLAR, despite existing evidence that students who use PLAR fare as well as or better than traditional students (Donoghue, Pelletier, Adams, \& Duffield, 2002; Dunlop \& Burtch, 2003; Keeton, 2000; LeGrow, 2000; Pearson, 2000). What may be needed to convince them to venture further with PLAR is evidence that suits the highly disciplinary nature of the university (Wong, 1999). This suggests that future PLAR research should adopt a disciplinary focus and examine topics such as PLAR availability and processes, discipline-specific assessment methods, and the academic success of students accessing PLAR in different fields of study. In addition, in-depth case studies of PLAR implementation and current practice at those institutions that have embraced PLAR most broadly would assist in its further development in the Canadian university sector.

\section{REFERENCES}

Aarts, S., Blower, D., Burke, R., Conlin, E., Lamarre, G., McCrossan, W., et al. (2003). Feedback from learners: A second cross-Canada study of prior learning assessment and recognition. Toronto: Cross-Canada Partnership on PLAR.

Association of Universities and Colleges of Canada. (2003). Myth: Adults don't go to university to acquire and upgrade their skills [Electronic Version]. Reality Check, 1, np. Retrieved January 6, 2006 from http://www.aucc.ca/_pdf/ english/publications/reality_check/adult_ed_e.pdf.

Ballim, Y., Omar, R., \& Ralphs, A. (2000). Learning assessment in South Africa. In N. Evans (Ed.), Experiential learning around the world (pp. 181-196). London: Jessica Kingsley Publishers.

Barkatoolah, A. (2000). From competence audit to APEL: The French experience of APEL in higher education. In S. Bailie, C. O'Hagan \& A. Mason (Eds.), APEL and Lifelong Learning (pp. 27-35). Belfast: University of Ulster.

Belanger, C. H., \& Mount, J. (1998). Prior learning assessment (PLA) in Canadian universities. Canadian Journal of Higher Education, 38(2/3), 99-120.

Blower, D. (2000). Canada: The story of prior learning assessment and recognition. In N. Evans (Ed.), Experiential Learning Around the World (pp. 83102). London, England: Jessica Kingsley Publishers Ltd.

Brown, J. 0. (2002). Know thyself: The impact of portfolio development on adult learning. Adult Education Quarterly, 52(3), 228-245.

Carrie, J., Ferguson, R., FitzGibbon, J., Kerlin, S., O’Leary, D., Train, B., et al. (2001). Prior learning assessment practices in British Columbia 2000/2001 PLA survey - Selected results. Retrieved. from http://www.aved.gov.bc.ca/pla/ welcome.htm\#instructors. 
Childs, M., Ingham, V., \& Wagner, R. (2002). Recognition of prior learning on the web - a case of Australian universities. Australian Journal of Adult Learning, 42(1), 39-56.

Council for Adult and Experiential Learning. (2002). Policies and initiatives of state higher education board that encourage working adults to pursue postsecondary degrees: A CAEL public policy brief. Chicago, IL: CAEL.

Dif, M. H. D., Alsace, B. C., \& Strasbourg, U. L. P. o. (2002, Sept. 11-14). Accreditation of experiential learning in France: Evaluation and perspectives. ECER 2002 (EERA/VETNET) symposium on the development of European methodology for the accreditation of prior experiential learning in lifelong learning. Retrieved Dec. 13, 2005, from http://www.b.shuttle.de/wifo/abstract/!ecer02p.htm

Donoghue, J., Pelletier, D., Adams, A., \& Duffield, C. (2002). Recognition of prior learning as university entry criteria is successful in postgraduate nursing students. Innovations in Education and Teaching International, 39(1), 54-62.

Dunlop, C., \& Burtch, B. (2003). Doors close, windows open: A British Columbia case study on widening access. Journal of Adult and Continuing Education, 9(1), 2-21.

Evans, N. (2000a). AP(E)L: Why? Where? How? Setting the international scene. In N. Evans (Ed.), Experiential learning around the world (pp. 15-29). London, England: Jessica Kingsley Publishers Ltd.

Evans, N. (2000b). The evolution of AP(E)L in England. In N. Evans (Ed.), Experiential learning around the world (Vol. 1, pp. 49-82). London: Jessica Kingsley Publishers Ltd.

Feutrie, M. (2000). France: The story of la validation d'aquis (recognition of experiential learning). In N. Evans (Ed.), Experiential learning around the world (pp. 103-116). London: Jessica Kingsley Publishers.

Flowers, R., \& Hawke, G. (2000). The recognition of prior learning in Australia: An ambivalent relationship with the academy, competency-based education and the market. In N. Evans (Ed.), Experiential learning around the world (pp. 151-166). London: Jessica Kingsley Publishers.

Foster, A. L. (2003). Colleges find more applicants through personalized web recruiting. Chronicle of Higher Education, 49(3), 37-38.

Geerling, F. S. H. (2003). Adult learning to reflect: A study of assessment of prior private learning. Unpublished Doctoral dissertation, Michigan State University.

Harris, J. A. (2004). The hidden curriculum of the recognition of prior learning: a case study. Unpublished Doctoral dissertation, Open University, London, England.

Hossler, D. (1999). Effective admissions recruitment. New Directions for Higher Education, 108(Winter), 15-30. 
Johnson, B. (2002). Models of APEL and quality assurance (1 ed.). Essex, UK: Southern England Consortium for Credit Accumulation and Transfer, SEEC.

Keast, D. (2000). Studying part-time at university: From research to policy and practice. Canadian Journal of Higher Education, 30(1), 57.

Keeton, M. T. (2000). Recognizing learning outside of schools in the United States of America. In N. Evans (Ed.), Experiential learning around the world (pp. 31-48). London, England: Jessica Kingsley.

Kennedy, B. (2003). A Spring 2003 snapshot of the current status of prior learning assessment and recognition (PLAR) in Canada's public post secondary institutions. Toronto: Council of Ministers of Education, Canada.

Ker, P., Melrose, M., \& Reid, M. (2000). Recognition of prior learning: The promise and the reality for New Zealanders. In N. Evans (Ed.), Experiential learning around the world: Employability and the global economy (pp. 167-180). London: Jessica Kingsley.

Kreber, C., \& Minha, C. (2005). Just plain rhetoric? An analysis of mission statements of Canadian universities identify their verbal committments to facilitating and promoting lifelong learning. Canadian Journal of University Continuing Education, 31(1), 51-86.

Larose, G. (2000). European and Asian credit transfer system: The view from a Canadian university perspective. Ottawa: Association of Universities and Colleges of Canada.

LeGrow, M. R. (2000). Prior learning assessment: Impact of APL portfolio development on problem solving skills and knowledge organization. Unpublished doctoral dissertation, University of Connecticut.

Livingstone, D. W., Raykov, M., \& Turner, C. (2005). Canadian adults' interest in prior learning assessment and recognition (PLAR): A 2004 national survey. Retrieved June 18, 2006, from http://wall.oise.utoronto.ca/PLAR/PLAR_ REPORT_Nov\%2705.pdf

Merrifield, J., McIntyre, D., \& Osaigbovvo, R. (2000). Mapping APEL: Accreditation of prior experiential learning in English higher education institutions. London: Learning from Experience Trust.

McGrath, D. (2000). The Republic of Ireland: The story of the assessment of prior experiential learning. In N. Evans (Ed.), Experiential learning around the world (pp. 135-150). London: Jessica Kingsley Publishers.

Michelson, E. (1996). Beyond Galileo's telescope: Situated knowledge and the assessment of experiential learning. Adult Education Quarterly, 46(4), 185196.

Organisation for Economic Co-operation and Development. (2005). Promoting adult learning. Paris: OECD. 
Organization for Economic Cooperation and Development. (2002). Thematic review on adult learning: Canada. Paris: OECD.

Patton, M. Q. (2002). Qualitative research \& evaluation methods (3rd ed.). Thousand Oaks, CA: Sage.

Pearson, W. S. (2000). Enhancing adult student persistence: The relationship between prior learning assessment and persistence toward the baccalaureate degree. Unpublished doctoral dissertation, Iowa State University, Ames, Iowa.

Peruniak, G. (1998). The promise of experiential learning. Canadian Journal of University Continuing Education, XIX(1), 9-29.

PLA Centre. (2001). Halifax declaration for the recognition of prior learning 2001. Recognizing Learning Conference. Retrieved June 18, 2006, from http:// www.placentre.ns.ca/visitors/special.php

Shalem, Y., \& Steinberg, C. (2002). Invisible criteria in a portfolio-based assessment of prior learning: A cat and mouse chase. Pedagogy, Culture and Society, 10(3), 425-448.

Shmyr, Z. (2003). Recognition of prior learning (RPL) within the newcomer community: A needs assessment final report. Regina: Saskatchewan Association of Immigrant Settlement and Integration Agencies (SAISIA).

Thomas, A. (2000). Prior learning assessment: The quiet revolution. In A. Wilson \& E. Hayes (Eds.), Handbook of adult and continuing education (pp. 508522). San Francisco: Jossey-Bass.

Thomas, A., Collins, M., \& Plett, L. (2002). Dimensions of the experience of prior learning assessment \& recognition (NALL working paper \#52). Toronto: OISE.

Thomas, A., \& Klaiman, R. (1992). The utilization of Prior Learning Assessment in Canada. Canadian Journal of University Continuing Education, XXIII(1), 7-26.

Thompson, G. (2000). Unfulfilled prophecy. The evolution of corporate colleges. Journal of Higher Education, 71(3), 322-341.

Wheelahan, L., Dennis, N., John, F., Miller, P., Newton, D., Pascoe, S., et al. (2002). Recognition of prior learning: policy and practice in Australia. Lismore, NSW, AU: Southern Cross University (Australia).

Wihak, C. (2005). State of the field review: Prior Learning Assessment and Recognition (PLAR). Ottawa, ON: Canadian Council on Learning.

Wong, A. (1999). Prior Learning Assessment \& Recognition: A Guide for university faculty \& administrators. Saskatoon: University of Saskatchewan.

Wong, A. (2000). University-Level Prior Learning Assessment and Recognition. Saskatoon: University of Saskatchewan. 
Wong, A. (2001). Prior Learning Assessment: Looking back, looking forward. In D. Poonwassie \& A. Poonwassier (Eds.), Fundamentals of adult education (pp. 159-170). Toronto: Thompson.

\section{CONTACT INFORMATION}

Dr. Christine Wihak

Faculty of Education

University of Calgary

2500 University Drive NW

Calgary, AB T2N 1N4

E-mail: cwihak@ucalgary.ca

Christine Wihak is an Assistant Professor in Workplace \& Adult Learning at the University of Calgary. An organizational psychologist with a strong interest in cross-cultural issues, she became interested in the potential of PLAR for adult learners while working with Inuit students enrolled in Management Studies at Nunavut Arctic College. 